\title{
Law reform in England and Wales: a shattered dream or triumph of political vision?
}

by The Hon Mr Justice Etherton

This is a slightly expanded version of the address delivered by The Hon Mr Justice Etherton, Chairman of the Law Commission, as the 2007 Sir William Dale Lecture at the Institute of Advanced Legal Studies on November 1, 2007, and of the address delivered as the 2007 Bar Law Reform Committee Lecture delivered in the Inner Temple Hall on November 14, 2007.

$\mathrm{T}$ he establishment of the Law Commission of England and Wales in 1965 marked a fundamental change in our constitutional arrangements. It ushered in the modern era of independent law reform.

The past 10 years have been a period of remarkable constitutional change. They come on top of a lengthy period in which the office of the Lord Chancellor and his Department have been transformed almost beyond recognition. Now the government has issued its green paper on the Governance of Britain, inviting a national debate about, among other things, a British Bill of Rights and Duties. There could not be a more opportune time to assess the historic success or otherwise of independent law reform in England and Wales and to anticipate its future.

\section{BEFORE THE CREATION OF THE COMMISSION}

In order to understand the quantum leap represented by the establishment of the Commission in 1965, it is necessary to place that event in its historical context.

It was the codification of the French civil law under Napoleon which provided the moral and intellectual impetus for systematic law reform in Britain. The codifiers conceived the idea of simplifying and re-stating the vast body of earlier law, so as to make the law more understandable and accessible to ordinary people. That inspired Jeremy Bentham and JS Mill in England, and their writings, in turn, promoted Parliamentary revision of English law. It led to the great era of codification and statute law revision (ie the repeal of obsolete or redundant statutes) in the $19^{\text {th }}$ century.

That process began in earnest in 1868 when Lord Chancellor Cairns appointed the Statute Law Committee with the remit of producing a revised edition of the statutes and of supervising progress on statute law revision and consolidation. There were 29 statute law revision Acts passed over the next 40 years or so, based mostly on recommendations of that Committee.

In 1934 Lord Sankey created the Law Revision Committee. This was the first standing law reform committee, that is to say concerned with reform of the law generally rather than merely the repeal and consolidation of existing statutes. It was a Ministerial committee, to which he appointed judges, barristers, solicitors and legal academics. It ceased to function in 1939.

In 1952 the English Law Reform Committee was established by Lord Chancellor Simonds to replace the earlier Law Revision Committee. That was where matters stood prior to the establishment of the Law Commission in 1965. The pattern up to this point is of a series of Ministerial committees, whose members were part time, and which were not in any way permanent or entrenched bodies.

\section{THE MOVEMENT FOR PERMANENT, INDEPENDENT LAW REFORM}

In 1963 the Society of Labour Lawyers sponsored the publication of a book Law Reform - Now, edited by Gerald Gardiner QC and Dr Andrew Martin. Gerald Gardiner, in particular, had by then become a strong critic of the many respects in which English law was unclear, inaccessible, outdated and unjust, and of the absence of a permanent body or mechanism equal to the task of remedying those defects.

The first chapter of the book, entitled "The Machinery of Reform", was written by Gerald Gardiner and Dr Martin. In that chapter they said that the problem of bringing the law up to date and keeping it up to date was 
largely one of machinery, and that the then existing machinery was not geared to steady, planned and coordinated operation. They said that nothing less would do than the setting up within the Lord Chancellor's Office of a strong unit concerned exclusively with law reform, including codification. They recommended that the head of the proposed unit should carry the rank of a Minister of State (who they called the Vice-Chancellor), who would be concerned exclusively with law reform and who would sit in the House of Commons.

They said that the Vice-Chancellor should preside over a committee of Law Commissioners, whose office and status would be established by statute. They would be full-time, and would not be ordinary civil servants, but would enjoy a high degree of independence. Their chief responsibility would be to review, bring up to date and keep up to date the general law, and they would do so by a plan for its systematic review. They should have an appropriate staff of legal assistants, at least some of whom would be trained in comparative research, as well as Parliamentary draftsmen.

The authors proposed that there should be a rule that no Parliamentary year should pass without the enactment of at least one Law Reform Act.

\section{THE CREATION OF THE COMMISSION}

Gerald Gardiner was very shortly afterwards in a position to transform into reality that vision of a permanent body devoted to bringing and keeping the law up to date. In 1964 he became Lord Chancellor in the first administration of Harold Wilson.

In 1965 that administration issued a white paper on the creation of a Law Commission for England and Wales and a Law Commission for Scotland. The same bold vision was set out. The white paper said:

"One of the hallmarks of an advanced society is that its laws should not only be just but also that they should be kept upto-date and be readily accessible to all who are affected by them. The state of the law today cannot be said to satisfy these requirements.

$\ldots$

it is today extremely difficult for anyone without special training to discover what the law is on any given topic: and when the law is finally ascertained, it is found in many cases to be obsolete and in some cases to be unjust. This is plainly wrong. English law should be capable of being recast in a form which is accessible, intelligible and in accordance with modern needs

There is at present no body charged with the duty of keeping the law as a whole under review and making recommendations for its systematic reform... it is evident that comprehensive reform can be achieved only by a body whose sole task it is and which is equipped with a professional staff on the scale required."
I turn to the scheme of the Law Commissions Act 1965 which, following the white paper, created the Law Commission of England and Wales. Section 1 of the 1965 Act provides for the appointment by the Lord Chancellor of five Law Commissioners, of whom one is appointed chairman. The Commissioners must be the holder of a judicial office, or be a barrister or solicitor or university law teacher. The Act provides for Commissioners to be appointed for a term not exceeding five years. The appointments are full time.

Until 2007, there was nothing in the 1965 Act which required the chairman to be a judge rather than one of the other categories of person qualified to serve as a Commissioner. Traditionally, however, the Chairman has been a serving High Court judge who has been appointed for three years. The Tribunals, Courts and Enforcement Act 2007 now provides that the chairman must be a judge of the High Court or of the Court of Appeal. Section 3 of the 1965 Act sets out the primary duty of the Law Commission
"to take and keep under review all the law [of England and
Wales]... with a view to its systematic development and reform, including in particular the codification of such law, the elimination of anomalies, the repeal of obsolete and unnecessary enactments, the reduction of the number of separate enactments and generally simplification and modernisation of the law..."

Section 3 of the 1965 Act then sets out the various different ways in which that objective may be achieved. It provides, among other things, for the preparation and submission from time to time to the Lord Chancellor of programmes of reform, as well as the undertaking of particular projects of reform at the request of government Departments, and the preparation of draft Bills to accompany the Commission's proposals for reform.

The Act provides for the programmes of reform proposed by the Commission to be approved by the Lord Chancellor, and that he shall lay them and the Commission's reform recommendations before Parliament. It also provides for an annual report by the Commission to be submitted to the Lord Chancellor and to be laid before Parliament.

The independence of the Commission is reflected in its status as a Non Departmental Public Body, and the fact that, while the Lord Chancellor has the legal power to decline to approve a programme of reform proposed by the Commission, neither the Lord Chancellor not anyone else has the power to compel the Commission to take on any particular project. The custom, and now the legal requirement, that the chairman must be a senior judge is also a powerful symbolic reflection of its independence. 


\section{THE WORK AND SUCCESS OF THE COMMISSION}

It is probably true to say that, outside of Parliament itself and the Departments of State, no body has had greater impact on the law and the lives of our citizens than the Law Commission since 1965. It has published 176 final reports on law reform, 43 reports on consolidation, and 17 reports on the repeal of obsolete statutes.

The Commission's reports on statute law revision have led to the repeal of more than 2000 Acts in their entirety and the partial repeal of several thousand other Acts. The repeal of obsolete statutes ought to be, of its nature, uncontentious. In the field of law reform, however, especially on the international stage, there is always the potential for the unexpected. In July 2006, for example, the Law Commission published its report on the repeal of expired statutes from the $17^{\text {th }}$ to $19^{\text {th }}$ centuries relating to turnpikes in Essex, Sussex and Norfolk. This prompted the following observations on a United States website under the heading "History at Risk - Turnpikes Under Attack from British Law reformers":

\footnotetext{
“Britain's great turnpike heritage is at risk. A panel of legal fussies called the Law Commission are trying to purge hundreds of harmless old turnpike laws from the British statutes - news that confirms once again the wisdom of the US Declaration of Independence and of General George Washington's small war in the 1770's to rid us of these misguided overlords... The first question for this Honourable Mr Justice Sir Terence Etherton (let's just call him Terence, eh?) at the next press conference of the Law Commission surely is: 'What do you propose The Hon Mr Justice Sir Terence if you delegislate turnpikes to have in place of the Jersey Turnpike as the opening scene for the Sopranos?... "”
}

It is in the field of law reform, however, that the Law Commission has played its most influential role in society. Over two thirds of its law reform reports have been implemented in whole or in part. A further 5 per cent have been accepted by government, but have not yet been implemented. A further 10 per cent are awaiting government response. Accordingly, almost three quarters of Law Commission law reform reports have been accepted in whole or in part by successive governments.

The areas of law and activity covered by those reports which have been accepted and implemented by government, or have been accepted in principle and await implementation, are highly diverse.

About 90 Acts of Parliament enacted since 1965 have contained Law Commission recommendations. The Defective Premises Act 1972, the Matrimonial Causes Act 1973, the Inheritance (Provision for Family and Dependants) Act 1975, the Unfair Contract Terms Act 1977, the Civil Liability (Contribution) Act 1978, the Sale and Supply of Goods Act 1994, the Family Law Act 1996, the Law of Property (Miscellaneous Provision) Act 1989 and the Land Registration Act 2002 are just a few examples in the area of civil law.

The Commission has also enjoyed particular success in the field of criminal law. Recent statutes incorporating Law Commission recommendations include the Criminal Justice Act 2003, the Domestic Violence, Crimes and Victims Act 2004, the Fraud Act 2006, and, with its enactment on 30 October this year, the Serious Crime Act 2007 (which gives effect to our proposals for new offences of assisting and encouraging crime). In the range of its work, the high standard of its reports, and its national and international standing, the Law Commission stands preeminent among the 60 or more law reform bodies in the world.

\section{HISTORICAL PATTERN OF SUCCESS}

Why then is there a view of many lawyers that the Commission, like Dr Johnson's view of second marriage, is a triumph of hope over experience? There is no doubt that the most successful period in the history of the Law Commission was in its first five years. During that time the Law Commission published 24 law reform reports, 22 of which were accepted and implemented in their entirety and the remaining two in part. Although that record has never subsequently been matched, the entire period to 1990 is impressive.

Taking successive five year periods between 1965 and 1990, the statistics show that government accepted in whole or in part not less than 70 per cent of the law reform reports of the Law Commission published during those periods, and all those reports which were accepted have been implemented. The period to 1990 may be graphically contrasted with the period since then. In the five years 1996-2000, the Law Commission published 17 reports, of which 47 per cent have been accepted and implemented, 12 per cent have been accepted but still await implementation, and no less than 35 per cent still await government response. In the following five years 20012005 the Commission published 20 reports, of which 35 per cent have been accepted and implemented, a further 25 per cent have been accepted but still await implementation, and a further 20 per cent still await government response.

This means that, in relation to the Commission's law reform reports published during the period 1996-2000, no less than 47 per cent have never been rejected by the government, but still await implementation or, at any event, some government decision and action. For the period 2001-2005, the comparable statistic is 45 per cent of Law Commission law reform reports. In most cases where the government has simply failed to respond to reports during those years, the lack of response falls well outside the two and a half year period (since publication) within which Departments are required, according to the terms of the protocol which I will describe later, to give a 
definitive decision specifying whether they accept or reject the Commission's recommendations.

\section{ANALYSIS OF PAST, PRESENT AND FUTURE PROBLEMS}

Looking back on the last 42 years of the Commission, I believe it is possible to identify the causes of the difficulties which the Commission has increasingly encountered in its relations with government. The analysis does not involve blame, but rather identifies political, legislative and governmental changes that have had a profound effect on the relations between the executive and the Law Commission, as they have had on other bodies.

It is significant that the period 1966-1970, which was the most successful period in the history of the Commission, coincided with the Lord Chancellorship of Lord Gardiner. As we have seen, he had a passionate and principled interest in the reform of the law to make it more modern, accessible and just, and he was responsible for the establishment of the Commission to carry forward his vision.

Critically, he was Lord Chancellor at a time when his Department (then called the Lord Chancellor's Office) was extremely small with few politically sensitive functions. At the same time, he combined the roles of Head of the Judiciary, the Speakership of the House of Lords, and membership of the executive with a senior Cabinet position. The Lord Chancellor was a highly influential member of the government, not by virtue of the size of his Department or the range of its functions and their political sensitivity, but by virtue of the constitutional significance of his office independent of party politics. The combination of those special characteristics within the Lord Chancellor, when added to a principled interest in law reform, ensured enactment of good Law Commission proposals within a reasonable time frame.

The political landscape has changed dramatically over time. Today, the reality is that the Lord Chancellorship is a facet of being the Secretary of State for Justice. As such, the Lord Chancellor is a fully fledged party politician, shorn of any independent judicial or legislative role. True it is that, under the Constitutional Reform Act 2005, and by virtue of his oath, the Lord Chancellor is bound to respect the rule of law, defend the independence of the judiciary and ensure the provision of resources for the efficient and effective support of the courts. Nevertheless, the political reality is that, unlike the Lord Chancellors of former times, he is wholly within the Cabinet and in no real sense or respect detached from it. His influence is measured by the relative size and importance of his Department and his personal political standing. He does not therefore have the constitutional attributes of former Lord Chancellors, whose high standing and influence reflected the unique constitutional position and facets of the Lord Chancellor's Office.
At the same time, he heads a Department which, in its size, the range of its responsibilities, and their political sensitivity, bears no comparison with the former Lord Chancellor's office. While the formal change in the constitutional role of the Lord Chancellor, in particular the termination of his role as Head of the Judiciary and the Speakership of the House of Lords, date only from the constitutional reforms of 2005, that dramatic change can be seen as part of a process of politicisation which can be traced back to 1971 and gathered increasing pace in the 1980s.

The Lord Chancellor took over the running of the Court service under the Courts Act 1971. More importantly, he took over responsibility for criminal legal aid in 1980 and civil legal aid in 1988. Responsibility for those matters, with all their implications for civil and legal justice and for significant slices of the national budget, inevitably brought a new party political edge to his position. More recently, as part of the same trend, his Department has taken on responsibility for the Magistrates Courts, for criminal law policy and for the prison service.

Those changes are reflected in the departmental budget. The DCA departmental report to Parliament for 2006-7 estimated the total amount to be spent during that year on the justice system in England and Wales at $£ 3.49$ billion of which just over $£ 4$ million (ie $0.1 \%$ ) was attributable to the Law Commission. Those changes have historically had an obvious harming effect on the sponsorship role of the DCA and now the MoJ for the Commission.

The vision in "Law reform - Now" of a strong unit in the Lord Chancellor's office headed by a Minister of State concerned exclusively with law reform has been translated in practice today into a very small sponsorship team located in the HM Court Service section of the Department. That insouciant administrative pigeonholding of the Commission within a court delivery service reflects both an awkward confusion or embarrassment as to how to deal with the Commission and, more particularly, a reflection of its low priority within a Department dealing with a wide range of highly politically charged and resource intensive functions.

Alongside these historical developments, and bound up with them, is the remarkable increase in legislation giving effect to party manifesto obligations, and general political policy initiatives, including matters of the moment. The number of pages of legislation nearly trebled in the 40 years 1965-2005 from 7567 pages in 1965 to approximately 20,800 pages in 2005. In addition to this increase the size of each page of legislation has also increased by 11 per cent. Since 1997 there have been 455 Public General Acts and more than 37,000 statutory instruments.

The marked increase in legislative activity across government has inevitably restricted the Parliamentary time available for enactment of non-political, non-party 
Law Commission reports. With Ministers and Departments competing vigorously for a share of the limited Parliamentary time available each session, priority is understandably claimed for those initiatives which will best secure votes and the political support of the electorate.

That tension between the Commission's law reform proposals and other more politically charged policy initiatives has had and continues to have its impact not merely at Cabinet level, in the legislative programme committee, but within each Department, including the DCA and now the MoJ. Resources are concentrated within Departments, including the MoJ, on those matters which are judged to be of greatest political value or present the greatest political risk.

Another feature of modern political life is the increased movement of Ministers, particularly junior Ministers, between and within Departments. For example, within the last 15 months since I was appointed chairman of the Commission, there have been no fewer than four junior Ministers in the DCA/MoJ with responsibility for the Law Commission, that is to say averaging less than four months each.

By contrast, experience has shown that it would be extremely difficult for the usual Law Commission project to be completed, with a draft Bill, in under three years. This disparity between the life of a project and the movement of junior Ministers within Departments means that there can be no assumption that a project supported, and even promoted, by a Department will be regarded with the same enthusiasm, or indeed any enthusiasm, at its conclusion.

\section{PAST SOLUTIONS}

Successive Lord Chancellors have not been unsympathetic to the difficulties faced by the Law Commission in securing implementation of its reports. With varying degrees of enthusiasm and success, they have sought to find ways to alleviate at least some of the problems.

So far as concerns the Law Commission's work on consolidation and the repeal of obsolete statutes, an appropriate Parliamentary procedure was early and easily found by bringing the Commission's recommendations within the ambit of the existing Joint Parliamentary Committee on Consolidation Bills and the expedited Parliamentary procedure applicable to them. This accounts for the 100 per cent success rate of the Law Commission's proposals in those areas.

A number of initiatives have been tried to facilitate and expedite the passage through Parliament of the Commission's law reform proposals. None have proved successful in the long term. In particular, attempts have been made from time to time to shorten the time taken on the floor of each House by Law Commission-inspired Bills by moving part of the process off the floor and into committee. None of those initiatives has enjoyed enduring success because in every case the use of them has depended on the personalities, knowledge and inclinations of the government's business managers from time to time.

More recently, the government tried to introduce a special legislative procedure for Law Commission recommendations in the Legislative and Regulatory Reform Bill introduced in the House of Commons in January 2006. This was an important and welcome recognition of the inadequacy of Parliamentary procedures for the implementation of Law Commission proposals. By the time the Bill had passed through the Commons and was introduced in the Lords, clause 3 provided for a Minister to be able to implement by order recommendations of the Law Commission. The government abandoned that clause, however, at committee stage in the Lords following complaints that the House should have the ability to scrutinise the Law Commission proposals, and that under the clause 3 procedure there would be no facility for Parliament to make amendments.

Another important initiative was the setting up by Lord Irvine in 2000 of the Ministerial Committee for the Law Commission to promote the Law Commission as a resource within government. It now also has the formal role of advising the Lord Chancellor on acceptance of the Law Commission's proposals for its three yearly programmes of reform.

The Ministerial Committee is chaired by the junior Minister in the MoJ with responsibility for the Law Commission, and its members comprise the junior Ministers in the Departments with which the Commission has the closest contact. It has not been a success. It has proved difficult to secure the attendance of its members, and in the past they have sometimes sent officials in their place. It did not meet at all for a period of some 18 months prior to an attempt in July 2006 to revive it by the then Minister for the Law Commission and my predecessor, Roger Toulson. A meeting called earlier this year was inquorate, when only three Ministers attended.

Finally, in March 2003 John Halliday CB published a report on the Law Commission as part of the usual quinquennial cycle of review of NDPBs. Following his recommendations, a protocol was drawn up setting out the way in which the Law Commission and government should work together to achieve the objectives in the 1965 white paper and the 1965 Act. The protocol, which was last updated in 2006, is entitled "The Law Commission and Government - working together to deliver the benefits of clear, simple and modern law". It is a detailed, and thoroughly worthy and appropriate document. More often than not, however, civil servants within Departments are unaware of, or at any event proceed with disregard for, its contents; not least the requirements that Departments should aim to respond to reports within six months of 
publication, and must in any event give a definitive decision on whether they intend to implement the report within two and a half years of its publication.

\section{SOLUTIONS}

This litany of woes, groans and moans does not leave me dismayed. Far from it. The Law Commission remains an extraordinarily vibrant and highly productive reform agency, producing work of the highest quality. We are regularly consulted by, and advise, representatives of both established and emerging democracies about independent law reform. Within the UK, the Commission is admired and respected throughout government and Parliament, and, I believe, the legal profession and the judiciary.

Admiration, of course, particularly if based upon a distant record of success, is not enough. It is right that the Commission should ask itself, and continually re-assess, whether, and to what extent, it is successful, or indeed that it is providing value for money. This raises issues about the definition of success for an independent law reform agency such as ours. Legislative implementation of reports is, of course, a very important measure of success. It is not, however, the only measure, bearing in mind, among other things, that we are an advisory body and not an implementation agency. It is for the democratically elected government to decide precisely when reports should be enacted, and in some cases this happens a decade or more after the reports are published. It must be right, therefore, that at least one other appropriate criterion of success is the extent to which our reports are accepted by government, even if not implemented immediately.

In my view, other legitimate criteria of success are the contribution of our reports to academic discussion and research, and to the clarification and development of the law by the courts. I would also add that their contribution to debate within and outside the legislature, and in that way laying the ground for future developments, is important. This is not the time to consider further this important topic, and the need generally to promote a more sophisticated set of performance indicators than implementation.

Even limiting the criteria of success to acceptance by government and implementation, the Commission is not currently unsuccessful, as I have pointed out earlier. What we have to face, however, is the clear evidence that the effectiveness of the Commission within government has been steadily undermined by all the historical developments and changes since 1965 which I have mentioned earlier. Those trends will only intensify, not diminish. There is therefore an urgent need to seek solutions to the political, and what may be described as structural, problems facing the Commission in relation to timely consideration, acceptance and implementation of our reports by government.
Notwithstanding the difficulties and failures of past initiatives, I believe that practicable and realistic solutions can be identified, and the present government's encouragement of a national debate about civic rights, duties and citizenship provides a unique opportunity for the implementation of those solutions. It is also very good news that the present Lord Chancellor, Jack Straw, and the Minister of State for the Law Commission, Michael Wills MP, are both closely involved in the government's constitutional agenda and have expressed a strong interest in supporting and promoting the effectiveness of the Commission.

The starting point is to concentrate on, and to emphasise, the constitutional importance of the work of the Commission, rather than on the Commission as an institution. It is the constitutional right of the citizen to be subject to laws which are, in the words of the 1965 white paper, "accessible, intelligible and in accordance with modern needs". That was the principle which inspired the French codifiers over 200 years ago, Jeremy Bentham and JS Mills in England in the $19^{\text {th }}$ century, and Gerald Gardiner and the other proponents of the establishment of a permanent, independent Law Commission in the last century. The Law Commission was established, and its governing legislation is specifically worded, to promote that principle.

In delivering the Sixth Sir David Williams Lecture on "the rule of law" in November 2006 in Cambridge, Lord Bingham said that the first sub-rule of the rule of law is that the law must be accessible and so far as possible intelligible, clear and predictable. Section 1 of the Constitutional Reform Act 2005 provides that nothing in the Act adversely affects the existing constitutional principle of the rule of law. Section 17 sets out the oath to be taken by the Lord Chancellor on acceptance of office. In it he swears to respect the rule of law.

If the government fails in a timely manner to consider, and, where appropriate, accept and then implement Law Commission's recommendations, what matters is not whether the Commission has been slighted, but that the citizen has been denied the constitutional right to law which is accessible, intelligible and in accordance with modern needs.

It therefore seems to me entirely appropriate and desirable that this constitutional right of the citizen, and the concomitant duty of the Ministers of the Crown to secure it, should be clearly stated in the government's proposed Constitutional Renewal Bill or other legislation arising out of the Governance of Britain green paper. We have so proposed to the Lord Chancellor, and that proposal is currently under consideration.

Next, as I have said, there is within government both ignorance of, and knowing disregard of, the protocol which sets out in detail the way government should promote the objectives in the 1965 white paper and the 1965 Act by co- 
operating with the Commission and dealing with the Commission's reports in a timely and appropriate manner. The solution here is that there should be a statutory obligation on the Lord Chancellor to lay before Parliament a scheme embracing the principal features of the protocol.

Further, there should be a statutory obligation on the Lord Chancellor to lay before Parliament each year a report stating, in relation to each unimplemented proposal of Law Commission reports, whether it is proposed to implement it, and, if not, why not, and if it is to be implemented, when it is expected that will happen.

These last two sets of statutory provisions dealing with machinery are in practical support of the constitutional right of the citizen to law which is intelligible, accessible and in accordance with modern needs. They too should find a natural place in the constitutional reform legislation arising out of the Governance of Britain green paper. We have so proposed to the Lord Chancellor, and that proposal is also currently under consideration.

Although this legislation we have proposed would merely give statutory effect to what is, or is supposed to be, current principle and practice, the significance of the legislation would be profound. The fundamental right of the citizen to accessible, intelligible and modern law would, for the first time, be articulated in statute, the practical means of its promotion would become statutory, and Parliament would be its overseer.

Irrespective of any such proposed new legislation, the political changes I have outlined earlier, and their adverse impact on the response of government to Law Commission reports, make a strong case for greater Parliamentary scrutiny. The Commission needs to build a closer relationship with relevant Parliamentary select committees, including, in particular, the Justice Committee in the Commons and the Constitution Committee in the Lords, which can enquire into the government's acceptance and promotion of the work of the Commission, and hold the Executive to account.

Our efforts to achieve this have recently borne fruit. On October 24, 2007 the Chairman of the Constitution Committee wrote to Baroness Ashton, the leader in the Lords, asking for the government's plans for each outstanding Law Commission report and the reasons for the delay in responding to or implementing them. The letter also stated that it is the intention of the Committee to take evidence from the chairman of the Law Commission after publication of the Commission's next annual report. This is an important development in the relationship between Parliament, the Executive and the Commission.

There remains the difficult and enduring problem of securing time for Law Commission proposals in the government's crowded legislative programme. There is a modest glimmer of hope here. Following the abandonment by the government of clause 3 of the Legislative and Regulatory Reform Bill, Baroness Ashton and my predecessor, Roger Toulson, began to explore the possibility of an expedited procedure in the House of Lords for appropriate Law Commission Bills. Under that procedure a committee would be able, off the floor of the House, to consider technical or uncontentious Law Commission Bills, take evidence and make amendments. Such Bills would then complete all their remaining legislative stages in both the Lords and the Commons very rapidly. The initiative has faced hurdles, delays and difficulties, but it appears to command the support of the main opposition parties and of the Lord Chancellor. Baroness Ashton hopes to be in a position to conduct a pilot in the near future.

That procedure should assist considerably with several of the Commission's reports on more technical and less policy laden areas of the law, which have been accepted in principle by government but have not yet found a place in the legislative programme. What then to do about other reports of the Commission, which are acceptable in principle to the government but would not be appropriate for the new joint committee expedited procedure?

We have proposed that the government should adopt a protocol that, in addition to Bills processed through the joint committee expedited procedure, there should be at least one Law Commission Bill, which has been accepted in principle by the government, per session. As I mentioned earlier, that was the proposal of Gerald Gardiner and Dr Martin in 1963. That proposal is currently under consideration by the government.

Further, the Ministerial Committee should be chaired by the Lord Chancellor, rather than a junior Minister, and its members should be the political heads of Departments rather than junior Ministers. This would involve a much closer association of members of the Cabinet with the work of the Commission in general, and their personal endorsement of the Commission's programmes of reform in particular. This should increase substantially the prospect of continued political support at the highest level for the projects of the Law Commission from beginning to end. In the light of my discussions with Ministers, I regard this proposal as achievable.

Finally, there is a strong case for correcting what may be regarded as a structural defect in the existing statutory framework for the Law Commission. The work of the Commission crosses all departmental boundaries, as the list of our completed projects plainly shows. Yet approval of the programmes of reform lies with the Lord Chancellor who, as Secretary of State for Justice, is head of the MoJ.

History has shown only too clearly that the MoJ, in its previous incarnations, has increasingly failed effectively to promote the role of the Commission and to ensure compliance with the protocol in other Departments. In fact, the MoJ, in its previous incarnations, has had the 
worst record of all Departments in complying with the protocol. This is not due to any personal inadequacy of successive Lord Chancellors. These are merely the consequences of the same historical problems and trends identified earlier.

The statutory oath of the Lord Chancellor to uphold the rule of law, and the central role of the present Lord Chancellor in the programme of constitutional renewal, his political experience and seniority within the Cabinet, and his genuine commitment to the work of the Law Commission, make him a very desirable statutory sponsor of the Law Commission at the present time. On the other hand, and having an eye both to past history and a future time beyond the present incumbent, it seems logical and more appropriate that the specific function of approving the Law Commission's programmes of reform should be that of the Prime Minister, as the head of government.

There is no reason in principle why the Commission's programmes of reform must be approved by a lawyer, any more than the approval of the legislative programme for the government should be reserved to lawyers. Indeed, although the present Lord Chancellor is a barrister by training, under section 2 of the Constitutional Reform Act 2005 a future Lord Chancellor need not be a lawyer. Further, the Prime Minister is pre-eminently the person who must uphold, and should be seen to be upholding, the rule of law.

Under this proposal, the Ministerial Committee for the Law Commission would become a committee of the Cabinet, chaired by the Lord Chancellor, which would advise the Prime Minister on approval of the Commission's programme of reform. Although, under this proposal, the Lord Chancellor would remain the statutory sponsor of the Commission, the change would send the clearest message throughout the executive as to the importance of the work of the Commission, and would tie in the Prime Minister and the entire Cabinet to the approved programmes of reform.

This package of reforms would have a significant long term impact on the effectiveness of the Commission and, I predict, on the scope and nature of its work.

\section{THE WORK AND WORK PRACTICES OF THE COMMISSION}

In the very early days of the Commission its programmes of reform were dominated by the grand vision of codification of the entire law by statute. Its first programme of reform, for example, published in 1965, included codification of the law of contract and of the law of landlord and tenant. The second programme included codification of criminal law and family law. It soon became clear, however, that these ambitious projects of codification were too large, too consuming of time and resources, and insufficiently connected to the social, political and governmental concerns of the moment. They all petered out or were abandoned.

Today, each proposed project is assessed by the Commission against the three criteria of importance, suitability and resources before acceptance. No project would be considered suitable unless it had Departmental support. Nor would it satisfy the suitability or resource criteria if it would take too long to complete. In these times of rapid political, legal, social and Ministerial changes, any project that would take substantially longer than three years to complete, with draft Bill attached, risks losing government support by its completion.

Like the original grand design of codification, statutory consolidation will remain one of our core tasks, but it is of decreasing significance within our workload. This is partly because consolidation cannot be undertaken unless the law remains relatively settled while the consolidation is being prepared, an increasingly rare state of affairs.

It is also partly because of changes made in the 1970s to the way Parliament amends legislation. This is now routinely done by textual amendment. With modern electronic sources of legislation and existing reference material, anyone wishing to see the latest version of an Act can readily do so. The need to consolidate simply to take account of textual change has largely gone.

Moving back to the area of our law reform work, there are further important developments since the early years of the Commission which are worth mentioning. First, our projects now are vary rarely simply analyses of black letter law. Empirical research both here and abroad is nearly always a vital ingredient.

Second, and related to that, we recognise that the value and political acceptability of our reports turn in large measure on the practical impact they will have on society. It is government policy that an impact assessment must be conducted in relation to all new policies. Those assessments are carried out within Departments. We believe that the quality of our work, and the likelihood of its acceptance, will be substantially improved if we carried out our own impact assessments. We now, therefore, employ a full time economist.

Finally, we recognise that we must work even harder to engage the public in our work. In addition to the usual forms of consultation, we have recently experimented with a web forum, which enabled the public both to leave their own comments on our web site and to see and comment on the comments of others. This proved very successful.

\section{CONCLUSION}

What then is the answer to the question contained in the title to this lecture?

The establishment of the Law Commission was indeed a truly inspired vision, promoting in a radically new way the 
right of citizens to laws which are intelligible, accessible and which meet their needs. The Commission has achieved a quite remarkable impact on large areas of our national life in pursuit of that principle.

I am not in the slightest dismayed by the past or without hope for the future. The dream is not at all shattered. Its prospects are better than they have ever been, provided that the government and Parliamentarians are prepared, at this time of debate about citizenship, to take the steps necessary to meet the challenges thrown up by the political and governmental changes since 1965. I believe that they will, and that the Law Commission of England and Wales will continue to play a vital role in the constitutional life of this country, and to be a beacon to other democracies throughout the world. (c)

Sir Terence Etherton

Chairman, Law Commission 